\title{
Determination of Spray and Air Volume Requirement for High Density Plantation Mango Orchard
}

\author{
B. B. Badgire*, S. M. Mathur, R. K. Rathod and G. S. Tiwari \\ Department of Farm machinery and power Engineering, CTAE, MPUAT, \\ Udaipur-313001, Rajasthan, India \\ *Corresponding author
}

Keywords

Spray and Air Volume Requirement, Mango Orchard

Article Info

Accepted:

18 January 2020 Available Online: 10 February 2020

\section{A B S T R A C T}

\section{Effective pest control requires precise and uniform application of pesticide} on the target area. Air assistance in spraying system improves the deposition uniformly in the entire tree canopy. Requirement of spray volume and air volume is influenced by leaf area, leaf density and canopy volume of tree. It is of great importance to determine spray volume and air volume requirement in HDP mango orchard to achieve effective spraying and precise pest control. To assess spray volume and air volume requirement for spraying on HDP matured mango orchard, tree parameters canopy volume, mean leaf area, leaf density and total leaf area of tree were estimated. Spray volume and air volume requirement for HDP mango orchard spraying were calculated. The required spray volume application rate per hectare was ranged from $144.24 \mathrm{lit} / \mathrm{ha}$ to $216.36 \mathrm{lit} / \mathrm{ha}$ and air volume requirement was $2.50 \mathrm{~m}^{3} / \mathrm{s}$ for efficient spraying operation in HDP mango orchard.

\section{Introduction}

In India, horticulture has gained commercial tone in recent years and is an important component of Indian agriculture, having very significant share in the economy of the country. India has the advantage of diverse agro-climatic conditions that enables it to produce a wide range of horticultural crops round the year. The horticulture crops also provide better alternative for diversification of Indian agriculture in view of higher return The continuing decline in the availability of cultivable land, rising energy and land cost together with the mounting demand for horticultural produce, have given thrust to the concept of high density planting ( HDP) of horticultural crops (Reddy, 2004). 
To achieve effective spraying, air assisted sprayer is needed to operate correctly so that the required quantity of spray volume and air volume will be delivered on the target crop canopy.

The determine spray volume and air volume requirement in HDP mango orchard will help to finalize operating parameter for effective application of pesticide in high density mango orchard with minimum losses and environmental pollution.

\section{Materials and Methods}

\section{Tree parameters measurement}

Fox et al., (2008) revealed that for best possible results, sprayer air velocity, volume and drop spectra should match to tree size, shape and density of canopy. In air carrier sprayer, spray liquid is conveyed to the target by air. The volume of air required is equal to the volume of the tree for effective coverage. The original air present in the canopy volume should be replaced by spray laden air generated by air assisted sprayer.

Mango trees have different shape and size. The information regarding canopy size, canopy height, leaf area, leaf density and canopy volume is required to estimate the air volume and spray volume application on mango tree. The data was collected for kesar mango variety with 9 years of age for 25 matured trees, from high density mango orchard research farm of American Spring \& Pressing Works Private Limited popularly known as 'ASPEE' Agricultural Research and Development Foundation, Malad (W), Mumbai-400064 located at Tanasa Ta. Wada Dist. Palghar near Thane (Maharashtra).

The observation of overall canopy height above ground level, height to the point of maximum canopy diameter, height from ground to canopy skirt, canopy diameter parallel to the row were recorded (Fig.1). These tree parameters were measured with clinometer height gauge and a measuring tape.

\section{Leaf density}

Fifteen Mango trees of high density plantation were selected for measurement of leaf density (Fig.2). A cage box of size $0.5 \mathrm{~m} \times 0.5 \mathrm{~m} \mathrm{x}$ $0.5 \mathrm{~m}$ (Fig.3) was fabricated in the laboratory. This was fabricated from MS round bar of 5 mm diameter.

All the faces were kept open for insertion of leaves in the cage box. One of the trees was selected and cage box was randomly placed at top, middle and bottom zone of tree. Number of leaves covered in cage box at three locations were collected from the tree and the leaves were counted .The number of leaves divided by volume of cage box gave the Leaf density (LD) in number of leaves $/ \mathrm{m}^{3}$. Similar data were collected for other mango trees. Mean, SD and CV values were then calculated for all fifteen mango trees.

\section{Leaf area}

The leaf area was measured using portable leaf area meter android (Biovis leaf Av) device (Fig.4). The leaves were collected from top, middle and bottom positions of the 15 mango trees of HDP mango orchard and each leaf passed through the leaf area meter \& its length, width and area were recorded. Total leaf area for the tree was found out from the following formula as suggested by Jose (1987) and Thakare (2004).

Total leaf area per tree $\left(\mathrm{cm}^{2}\right)$

$$
=\text { leaf density }\left(\frac{\text { leaves }}{\mathrm{m}^{3}}\right) \times \text { cnopy volume }\left(\frac{\mathrm{m}^{3}}{\text { tree }}\right) \times \text { mean leaf area }\left(\mathrm{cm}^{2}\right)
$$




\section{Estimation of Air volume requirement for spraying HDP mango orchard}

The theoretical air volume $\left(\mathrm{m}^{3} / \mathrm{s}\right)$ required for HDP mango orchard was calculated as follows (Joseph, 1990).

Air volume $\left(\mathrm{m}^{3} / \mathrm{s}\right)=\frac{\text { Speed }\left(\frac{\mathrm{m}}{\mathrm{h}}\right) \times \text { Spray width }(\mathrm{m}) \times \text { Tree height }(\mathrm{m}) \times 1000}{6.5 \times 3600}$

Following assumptions were made:

a) The operating speed of $2.5 \mathrm{~km} / \mathrm{h}$ for spraying operation.

b) Operating spray width one side only, this is half of the mean canopy diameter of the mango tree and measured as $2.052 \mathrm{~m}$

c) Factor of safety for dense canopy is 6.5 . (Joseph, 1990).

Considering these assumptions, the air volume is as follows:

Air volume $\left(\mathrm{m}^{3} / \mathrm{s}\right)=\frac{2.5\left(\frac{\mathrm{km}}{\mathrm{h}}\right) \times 2.052(\mathrm{~m}) \times 4.66(\mathrm{~m}) \times 1000}{6.5 \times 3600}$

$=1.021=1.0$

Air volume $\left(\mathrm{m}^{3} / \mathrm{s}\right)=1.00 \mathrm{~m}^{3} / \mathrm{s}$

Therefore air volume of $1.0 \mathrm{~m}^{3} / \mathrm{s}$ required to spray one side of row of mango tree. To spray internal two sides of row of mango trees double air volume is required.

Air volume required for two internal sides of row $=2 \times 1=2 \mathrm{~m}^{3} / \mathrm{s}$

Considering the blower efficiency $80 \%$ (Wilson et al., 1962) for effective spraying, the air volume required is as follows

The air volume required $=2 / 0.8$

$$
=2.5 \mathrm{~m}^{3} / \mathrm{s}
$$

Therefore, the theoretical air volume required for efficient spraying in HDP mango orchard was $2.5 \mathrm{~m}^{3} / \mathrm{s}$.
Estimation of total leaf area and spray volume requirement for spraying HDP mango orchard

Total leaf area for the tree was found out from the following formula as suggested by Jose (1987) and Thakare (2004).

Total leaf area per tree $\left(\mathrm{cm}^{2}\right)=$

$$
=\text { leaf density }\left(\frac{\text { leaves }}{\mathrm{m}^{3}}\right) \times \text { cnopy volume }\left(\frac{\mathrm{m}^{3}}{\text { tree }}\right) \times \text { mean leaf area }\left(\mathrm{cm}^{2}\right)
$$

$$
\begin{aligned}
& =2521.6 \times 19.58 \times 91.63=4524041.39 \\
& \mathrm{~cm}^{2} / \text { tree }
\end{aligned}
$$

Mathews (1992) recommended 30 to $100 \mu \mathrm{m}$ droplet size for insects on foliage. To reduce the drift losses and dripping losses he considered $100-250 \mu \mathrm{m}$ droplet size and minimum droplet density ranging from 20 to 25 for $100 \mu \mathrm{m}$ droplet, 25 droplets of $100 \mu \mathrm{m}$ per sq.cm was considered (Thakare, 2004). After knowing the total leaf area per tree, the spray volume requirement per tree was calculated as follows:

Spray volume, lit $=\frac{\text { Totall leaf area pertree }\left(\mathrm{cm}^{2}\right) \times 225\left(\frac{\text { droplat }}{\mathrm{cm}^{2}}\right) \times \text { volume of a dropof of } 100 \mathrm{pm}\left(\mathrm{cm}^{\mathrm{m}}\right)}{1000}$

$=\left(4524041.39 \times 1.3089 \times 10^{-5} \mathrm{cc}\right) / 1000$

$=0.05922 \mathrm{lit} /$ tree $($ one side $)$

$=0.1184 \mathrm{lit} /$ tree $($ both side)

Herrington et al., (1981) reported that $80 \%$ of total canopy volume was occupied by leaves and hence only $80 \%$ of above spray solution was required for leaf coverage. Therefore assuming density adjustment factor as 0.80 , the spray volume in $1 /$ tree is as follows.

$=0.8 \times 0.0592 \mathrm{lit} /$ tree $($ one side $)=0.0474$

lit/tree (one side)

$=0.8 \times 0.1184$ lit $/$ tree (both sides)

$=0.09473 \mathrm{lit} /$ tree (both sides) 
Planas and Pons (1991) reported that for application volume rate of 100, 400, 1600 lit/ha, leaf deposits were 54.2, 76.6 and 74.7 $\%$ respectively. The other portion was lost by evaporation, drift and run-off. Hence for low volume application, $75 \%$ of spray volume is assumed as deposited on leaves out of total spray volume (Spray deposition factor $=0.75$ ).

Hence theoretical spray volume required liter per hectare considering spacing of $5 \mathrm{~m} \times 3.5$ and 571 trees/ha is as follows:

$=(0.09473 \times 571) / 0.75$

$=36.06 \mathrm{lit} / \mathrm{ha}$ (one side)

$=72.12 \mathrm{lit} / \mathrm{ha}$ (both side)

Considering factor of safety 2.0 for minimum spray application volume for spray application as two Dhande (2014). The spray volume per hectare will be

$=36.06 \times 2.00$

$=72.12 \mathrm{lit} / \mathrm{ha}$ (one side)

$=144.24 \mathrm{lit} / \mathrm{ha}$ (both sides)

Further considering factor of safety for maximum spray application volume for spray application as 3 Dhande (2014).

$=72.12 \times 3.00$

$=216.36$ lit $/$ ha (both sides)

Therefore spray volume application rate per hectare was ranged from $72.12 \mathrm{lit} / \mathrm{ha}$ to 216.36 lit/ha.

\section{Results and Discussion}

During the study, spray volume and air volume requirement for pesticide application on high density plantation mango tree was assessed for effective application of pesticide in high density mango orchard with minimum losses and environmental pollution.

\section{Physiological parameters of HDP mango} trees

Various tree parameters and canopy volume of 25 mango trees of $\mathrm{Cv}$. Kesar variety in HDP mango orchard are presented in table 1. The age of mango trees was 9 years. The canopy volume based on prolate spheroid formula and tree parameters were analyzed by statistical software. The minimum and maximum canopy volume was found to be $14.13 \mathrm{~m}^{3}$ and $30.67 \mathrm{~m}^{3}$ respectively. The mean canopy volume was $19.58 \mathrm{~m}^{3}$. The mean diameter parallel to the row, mean overall canopy height above ground level, mean height at maximum canopy diameter and mean height from ground to canopy skirt were found to be $4.10 \mathrm{~m}, 4.66 \mathrm{~m}, 2.67 \mathrm{~m}$ and 1.17 $\mathrm{m}$ respectively.

Similarly Table 2 shows various tree parameters and total leaf area of 15 mango tree of $\mathrm{Cv}$. Kesar variety in HDP mango orchard. The canopy leaf area and tree parameters obtained from biovis leaf area meter were analyzed by SAS statistical software. The minimum leaf area was found to be $61.39 \times 10^{-4} \mathrm{~m}^{2}$ and The maximum leaf area was found to be $125.01 \times 10^{-4} \mathrm{~m}^{2}$. The mean leaf area was found to be $91.63 \times 10^{-4} \mathrm{~m}^{2}$ The total mean leaf area of tree was found to be $29134.00 \times 10^{-4} \mathrm{~m}^{2}$. The mean leaf density was found to be 2521.6 per $\mathrm{m}^{3}$.

\section{Spray volume and air volume requirement of HDP mango tree for effective spraying}

The canopy volume and total leaf area of Mango trees were used to calculate the spray volume requirement per hectare of Mango tree considering the droplet density of 25 droplets $/ \mathrm{cm}^{2}$ of mean droplet diameter of $100 \mu \mathrm{m}$ as given by Mathews (1992) for effective pest control, spray deposition on both sides of leaves and the spray volume. The spray volume requirement for Mango tree are presented in table 3 . 
Table.1 Physiological parameters of HDP mango orchard of variety Cv Kesar.

\begin{tabular}{|c|c|c|c|c|c|}
\hline Sample no. & $\mathbf{D}_{1}(\mathbf{m})$ & $H_{t}(m)$ & $H_{c}(m)$ & $H_{s}(m)$ & $\mathbf{P S}_{\mathrm{cv}}\left(\mathrm{m}^{3}\right)$ \\
\hline 1 & 3.60 & 4.46 & 2.60 & 1.00 & 14.22 \\
\hline 2 & 4.10 & 4.90 & 2.71 & 0.95 & 30.67 \\
\hline 3 & 3.57 & 4.57 & 2.65 & 1.10 & 14.36 \\
\hline 4 & 4.70 & 5.10 & 2.80 & 1.20 & 28.20 \\
\hline 5 & 3.65 & 4.56 & 2.45 & 1.15 & 16.02 \\
\hline 6 & 4.25 & 4.71 & 2.70 & 1.25 & 20.46 \\
\hline 7 & 4.10 & 4.31 & 2.65 & 1.10 & 16.16 \\
\hline 8 & 3.80 & 4.15 & 2.41 & 1.10 & 14.47 \\
\hline 9 & 3.90 & 4.20 & 2.50 & 1.20 & 14.84 \\
\hline 10 & 4.30 & 4.81 & 2.81 & 1.31 & 20.86 \\
\hline 11 & 4.50 & 5.10 & 2.90 & 1.40 & 24.83 \\
\hline 12 & 4.15 & 4.71 & 2.75 & 1.20 & 19.22 \\
\hline 13 & 3.90 & 4.62 & 2.62 & 1.15 & 17.40 \\
\hline 14 & 3.85 & 4.81 & 2.51 & 1.10 & 19.26 \\
\hline 15 & 4.21 & 4.90 & 2.65 & 1.25 & 22.28 \\
\hline 16 & 4.60 & 4.90 & 2.70 & 1.15 & 25.92 \\
\hline 17 & 3.65 & 4.41 & 2.60 & 1.10 & 14.13 \\
\hline 18 & 3.85 & 4.61 & 2.71 & 1.00 & 16.46 \\
\hline 19 & 4.20 & 4.82 & 2.80 & 1.20 & 20.26 \\
\hline 20 & 3.95 & 4.30 & 2.75 & 1.15 & 14.26 \\
\hline 21 & 4.36 & 4.61 & 2.80 & 1.28 & 19.54 \\
\hline 22 & 4.10 & 4.55 & 2.61 & 1.10 & 18.58 \\
\hline 23 & 4.40 & 4.71 & 2.65 & 1.20 & 22.33 \\
\hline 24 & 4.51 & 4.75 & 2.71 & 1.25 & 21.77 \\
\hline 25 & 4.40 & 4.92 & 2.80 & 1.30 & 22.99 \\
\hline Minimum & 3.57 & 4.15 & 2.41 & 0.95 & 14.13 \\
\hline maximum & 4.70 & 5.10 & 2.90 & 1.40 & 30.67 \\
\hline mean & 4.10 & 4.66 & 2.67 & 1.17 & 19.58 \\
\hline S.D. & 0.32 & 0.26 & 0.12 & 0.10 & 4.57 \\
\hline C.V. & 0.08 & 0.06 & 0.04 & 0.09 & 0.23 \\
\hline
\end{tabular}

S.D.(Standard deviation), C.V. (Coefficient of variation), $\mathrm{PS}_{\mathrm{cv}}\left(\right.$ Canopy volume, $\left.\mathrm{m}^{3}\right)$,

$\mathrm{D}_{1}$ (Canopy diameter parallel to the row, $\left.\mathrm{m}\right), \mathrm{H}_{\mathrm{t}}$ (Overall canopy height above ground, $\mathrm{m}$ )

$\mathrm{H}_{\mathrm{c}}$ (Height at maximum canopy diameter, $\left.\mathrm{m}\right), \mathrm{H}_{\mathrm{s}}($ Height from ground to canopy skirt, $\mathrm{m}$ ) 
Table.2 Leaf area measurement of HDP mango trees for spray volume estimation

\begin{tabular}{|c|c|c|c|c|c|}
\hline $\begin{array}{l}\text { Sample } \\
\text { no. }\end{array}$ & $\begin{array}{c}\text { Number } \\
\text { of leaves } \\
\text { per } 0.125 \\
\text { m }^{3}\end{array}$ & $\begin{array}{c}\text { Mean } \\
\text { length of } \\
\text { leaf } \\
\left(\mathbf{m x 1 0}^{-2}\right)\end{array}$ & $\begin{array}{c}\text { Mean } \\
\text { width of } \\
\text { leaf } \\
\left(\mathrm{mx10}^{-2}\right)\end{array}$ & $\begin{array}{c}\text { Mean } \\
\text { leaf area } \\
\left(\mathbf{m}^{2} \times 1^{-4}\right)\end{array}$ & $\begin{array}{l}\text { Total leaf area } \\
\qquad\left(\mathrm{m}^{2} \times 10^{-4}\right)\end{array}$ \\
\hline 1 & 261.00 & 18.30 & 4.81 & 70.14 & 18306.54 \\
\hline 2 & 462.00 & 22.28 & 5.15 & 94.04 & 43446.48 \\
\hline 3 & 345.00 & 27.31 & 5.52 & 125.01 & 43128.45 \\
\hline 4 & 268.00 & 24.03 & 5.70 & 113.78 & 30493.04 \\
\hline 5 & 290.00 & 21.21 & 5.08 & 88.03 & 25528.70 \\
\hline 6 & 319.00 & 24.06 & 4.77 & 95.45 & 30448.55 \\
\hline 7 & 267.00 & 19.10 & 3.74 & 61.39 & 16391.13 \\
\hline 8 & 291.00 & 21.51 & 4.16 & 71.55 & 20821.05 \\
\hline 9 & 297.00 & 22.19 & 4.85 & 88.20 & 26195.40 \\
\hline 10 & 327.00 & 22.04 & 5.87 & 102.02 & 33360.54 \\
\hline 11 & 318.00 & 24.11 & 4.51 & 94.73 & 30124.14 \\
\hline 12 & 295.00 & 19.37 & 4.29 & 65.59 & 19349.05 \\
\hline 13 & 337.00 & 21.60 & 6.29 & 108.36 & 36517.32 \\
\hline 14 & 289.00 & 25.42 & 5.70 & 111.10 & 32107.90 \\
\hline 15 & 362.00 & 22.02 & 4.66 & 85.06 & 30791.72 \\
\hline Mnimum & 261.00 & 18.30 & 3.74 & 61.39 & 16391.13 \\
\hline Maximum & 462.00 & 27.31 & 6.29 & 125.01 & 43446.48 \\
\hline Mean & 315.20 & 22.30 & 5.01 & 91.63 & 29134.00 \\
\hline S.D. & 50.29 & 2.41 & 0.71 & 18.76 & 8260.56 \\
\hline C.V. & 0.16 & 0.11 & 0.14 & 0.20 & 0.28 \\
\hline $\begin{array}{l}\text { Leaf } \\
\text { density } \\
\text { per } \mathbf{m}^{3}\end{array}$ & 2521.6 & & & & $\begin{array}{c}23.3072 \\
\text { (Leaf area } \\
\left.\text { density, } \mathrm{m}^{2} / \mathrm{m}^{3}\right)\end{array}$ \\
\hline
\end{tabular}

S.D. $=$ Standard deviation

C.V. $=$ Coefficient of variation 
Fig.1 Measurement of canopy height and other tree parameters in HDP mango orchard

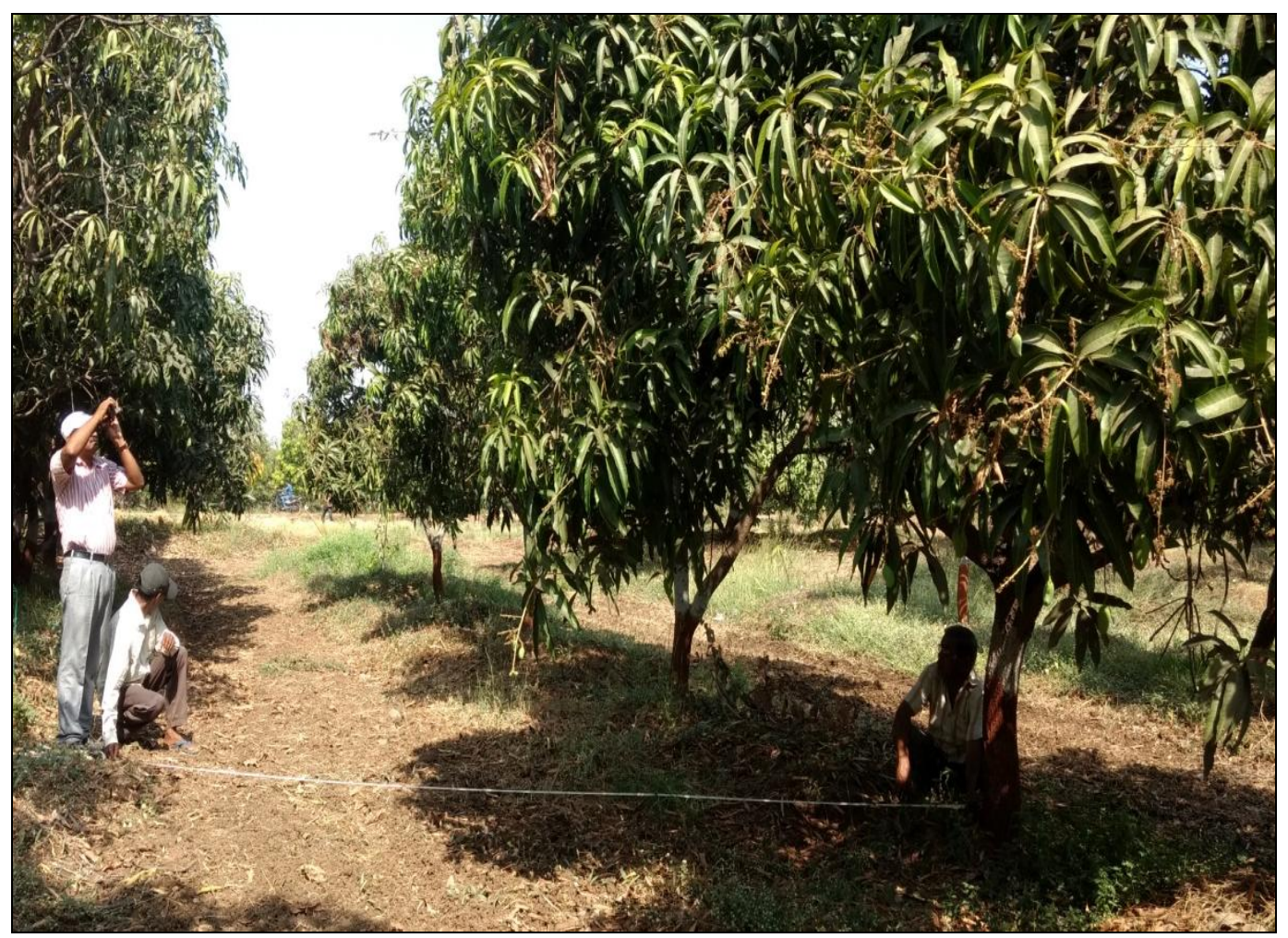

Fig.2 Measurement of leaf density of mango tree in HDP mango orchard

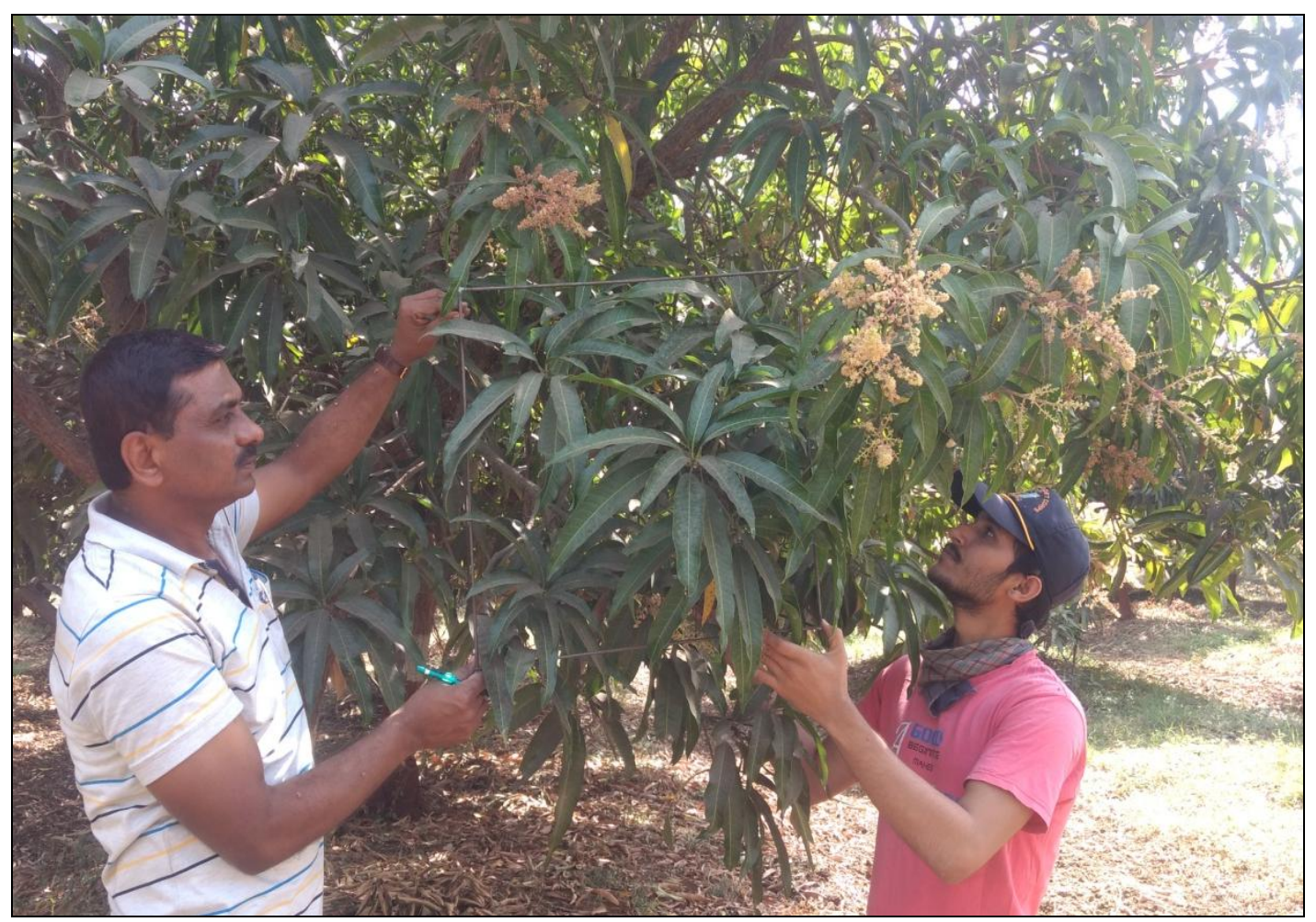


Fig.3 Cage box for measurement of leaf density of mango tree

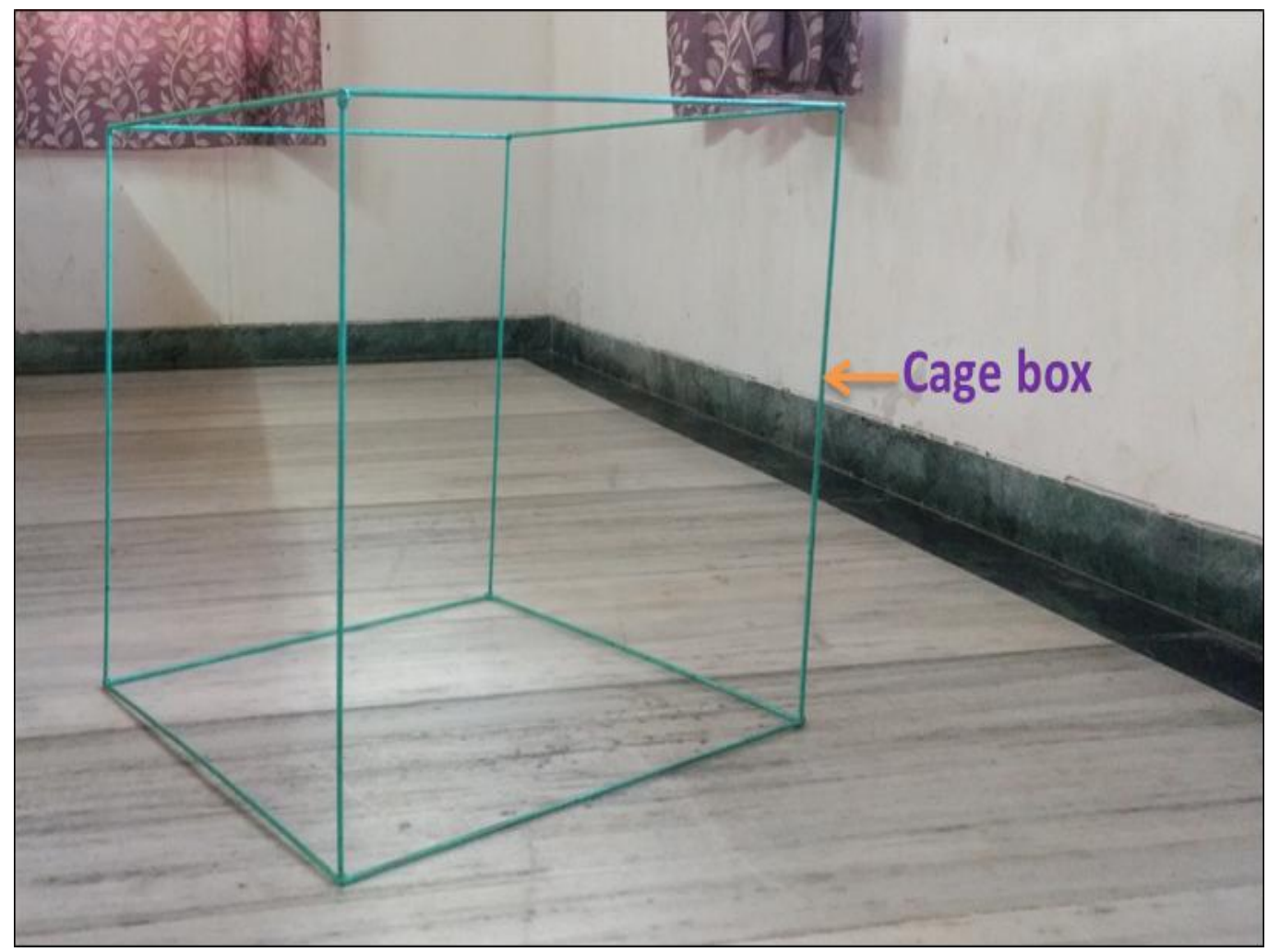

Fig.4.5 Biovis leaf area meter

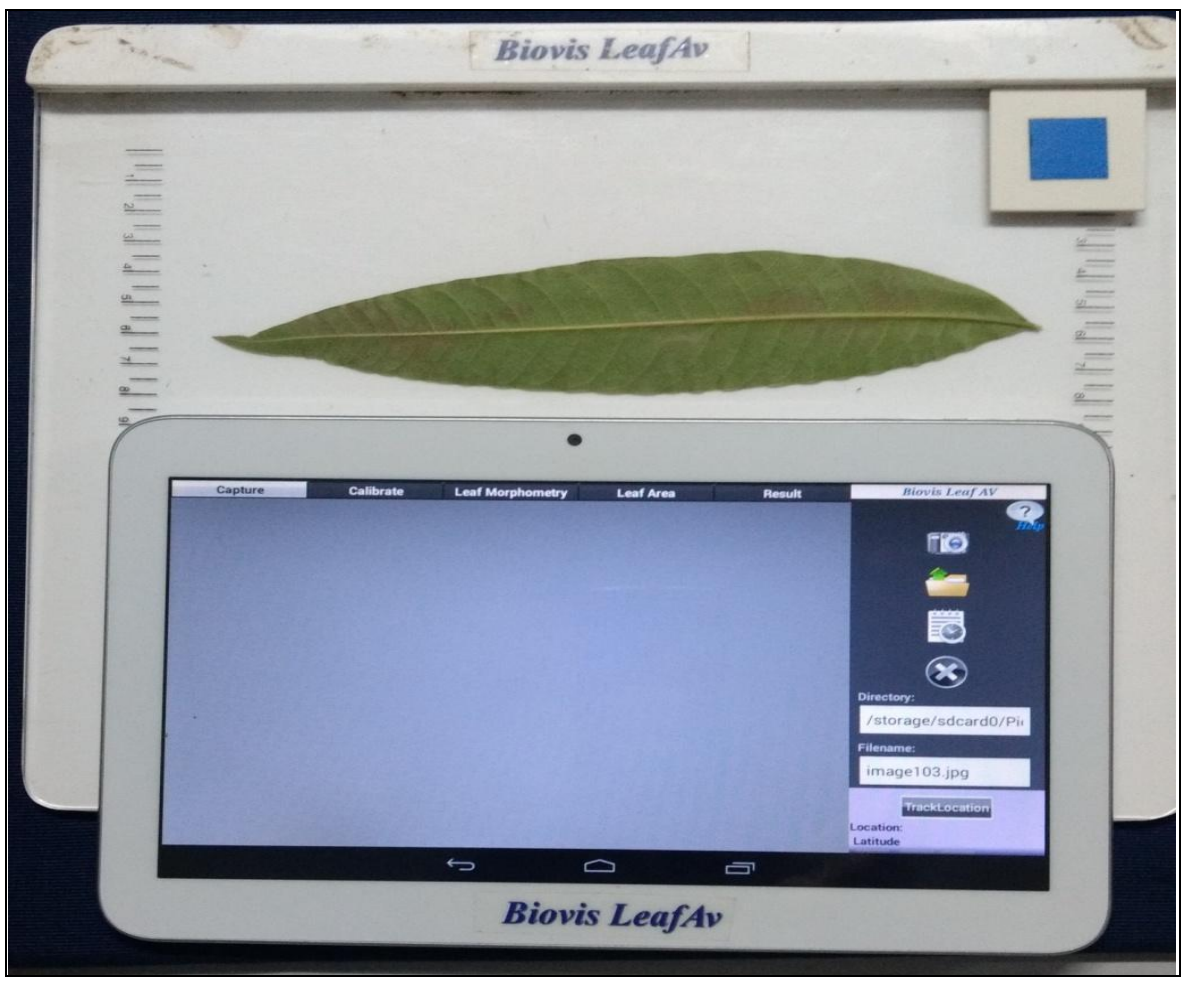


The Table 3 shows that the spray volume ranged from $0.126 \mathrm{l} /$ tree to $0.380 /$ tree and $72.12 \mathrm{l} / \mathrm{ha}$ to $216.36 \mathrm{l} / \mathrm{ha}$ and air volume requirement for effective pest control before dripping off droplets from the leaves. The spray volume adjustment is used for tree size, leaf characteristics and canopy density. Travis (1987) also found that canopy form and volume generally have a much greater effect on spray volume and spray deposit. Where a constant rate of active ingredient per hectare is applied, the quantity deposited increases with decreasing spray volume. This is attributed to lower runoff and drift losses with low volume sprays. It is probable that smaller droplet size contributes to increase in spray retention at reduced spray volume. Thus air and spray volume requirement of mango tree in HDP orchard for pesticide application by aero blast (air assisted) sprayer could be fairly estimated for efficient and effective spraying by canopy and leaf characteristics. This would reduce drift and dripping and minimizing the spray volume requirement and reduce cost of operation.

On the basis of research carried out and result obtained the following conclusion were drawn.

Air volume requirement of aero blast sprayer for HDP mango orchard was found 2.5 $\mathrm{m}^{3} / \mathrm{s}$.

The spray volume requirement ranged from $0.126 \mathrm{l} /$ tree to $0.380 /$ tree and $72.12 \mathrm{l} / \mathrm{ha}$ to 216.36 1/ha.

\section{References}

Dhande, K. G. 2014. Design and development of centrifugal blower and rotary atomizer of air-assisted sprayer for Mango orchard. Unpublished Ph.D Thesis. MPUAT Udaipur (India)

Jose, K.J. 1987. Field performance of spray nozzles on cotton crop. Unpublished M.Tech. thesis, IIT, Kharagpur .

Joseph, M. B. 1990. Calibration of mist blower. Applied Technology Course, Hardi Publications, Leida Spain: 1-4.

Pompe, J. C. A. M. and Holterman, H. J. 1992. Technical aspects of pesticide application Wageningen Agriculture University.

Reddy, B.M.C. 2004. High density planting in horticultural crops. First Indian Horticulture Congress, $\quad 6^{\text {th }}-9^{\text {th }}$ November, New Delhi p. 36.

Thakare, S.K. 2004. Design, development and performance evaluation of air-assisted sleeve boom for tractor mounted sprayer. Ph.D. thesis submitted to MPUAT, Udaipur, Rajasthan, India.

Travis, J. N. 1987. Effect of travel speed, application volume and nozzle arrangement on deposition and distribution of pesticide in apple trees. Plant Disease, 71: 606-617.

Wilson and Irons. 1962. The swath pattern of tomato disease control with air blast sprayers. The Ohio Agricultural Experiments Research Station. Circular No.77.

\section{How to cite this article:}

Badgire, B. B., S. M. Mathur, R. K. Rathod and Tiwari, G. S. 2020. Determination of Spray and Air Volume Requirement for High Density Plantation Mango Orchard. Int.J.Curr.Microbiol.App.Sci. 9(02): 2406-2414. doi: https://doi.org/10.20546/ijcmas.2020.902.274 